\title{
Farm management factors associated with bulk tank total bacterial count in Irish dairy herds during 2006/07
}

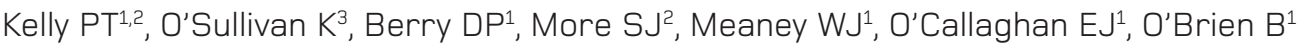

${ }^{1}$ Moorepark Dairy Production Research Centre, Fermoy, Co. Cork

2 School of Agriculture, Food Science and Veterinary Medicine, University College Dublin, Belfield, Dublin 4

${ }^{3}$ Department of Statistics, School of Mathematical Sciences, University College Cork, Co. Cork

\section{ABSTRACT}

Research has shown that total bacterial count (TBC), which is the bacterial growth per ml of milk over a fixed period of time, can be decreased by good hygiene and farm management practices. The objective of the current study was to quantify the associations between herd management factors and bulk tank TBC in Irish spring calving, grass-based dairy herds. The relationship between bulk tank TBC and farm management and infrastructure was examined using data from 400 randomly selected Irish dairy farms where the basal diet was grazed grass. Herd management factors associated with bulk tank TBC were identified using linear models with herd annual total bacterial score (i.e., arithmetic mean of the natural logarithm of bulk tank TBC) included as the dependent variable. All herd management factors were individually analysed in a separate regression model, that included an adjustment for geographical location of the farm. A multiple stepwise regression model was subsequently developed. Median bulk tank TBC for the sample herds was $18,483 \mathrm{cells} / \mathrm{ml}$ ranging from 10,441 to 130,458 cells $/ \mathrm{ml}$. Results from the multivariate analysis indicated that the following management practices were associated with low TBC; use of heated water in the milking parlour; participation in a milk recording scheme; and tail clipping of cows at a frequency greater than once per year. Increased level of hygiene of the parlour and cubicles were also associated with lower TBC. Herd management factors associated with bulk tank TBC in Irish grazing herds were generally in agreement with most previous studies from confinement systems of milk production.

KEYWORDS: bulk tank, dairy cattle, infrastructure, management, total bacterial count

\section{CORRESPONDING AUTHOR:}

Patrick T Kelly

Moorepark Dairy Production Research Centre, Fermoy, Co. Cork, Ireland

Tel: +35325 42222

Fax: +35325 42340

E-mail: paddy.kelly@teagasc.ie

\section{INTRODUCTION}

Total bacterial count (TBC) is the bacteria growth per $\mathrm{ml}$ of milk over a fixed period of time (Blowey and Edmondson 1995). High TBC milk should be avoided since some bacteria (Staphylococcus aureus, Escherichia coli and Streptococcus agalactiae) found in raw milk can cause diarrhoeal disease and food poisoning (Gilmour and Rowe 1990). After pasteurisation, the risk of illness to humans can occur by recontamination of milk through milk pipes and stored milk residues or by thermoduric bacteria (Bacillus cereus) which can survive pasteurisation (Gilmour and Rowe 1990). Bacteria can also have a negative effect on dairy products. For example, Alteromonas putrefaciens causes a surface taint in butter, and E. coli can spoil milk and dairy products by gas production during storage (Gilmour and Rowe 1990). Accordingly, milk quality is required to be within certain thresholds according to European law (EEC, 1992, Council Directive 92/46/EEC); total bacterial count must not exceed a geometric average of 100,000 per $\mathrm{ml}$ over two months, with at least two tests per month. Additionally, incentives (TBC less than 30,000 ) and penalties are applied by milk processors to help ensure high milk quality. Recent research indicates a general tendency for bulk tank TBC in Ireland to decrease between the years of 1994 to 2003, but this was followed by an increase between 2003 and 2004 (Berry et al. 2006).

Milk is synthesised in epithelial cells of the mammary gland and is virtually sterile when secreted into the alveoli of the udder (Tolle 1980). Thus, contamination of milk largely occurs subsequent to milk synthesis. According to Bramley and McKinnon (1990), the three main areas or sources of microbial contamination are from within the udder subsequent to synthesis, the exterior of the udder and the surface of milk handling and storage equipment. Bacteria can multiply through poor hygiene and 
sanitation and subsequently be flushed into the bulk tank, increasing the TBC (Hayes et al. 2001). An increase in TBC can be related to mastitis organisms, environmental contaminants, dirty milking equipment or failure of refrigeration (Blowey and Edmondson 1995). Jayarao et al. (2004) documented that herd size and farm management practices influence bacterial counts in bulk tank milk. Furthermore, Hogan et al. (1990) reported that bedding material was a source of bacteria, and Natzke (1981) documented that an increased plate loop count was associated with poor maintenance of the milking machine. Also, Goldberg et al. (1992) reported that confined housing resulted in a higher bacteria level in milk, as measured by a standard plate count, than an intensively managed rotational grazing system.

The objective of the current study was to quantify the associations between herd management factors and bulk tank TBC in Irish spring calving, grass-based dairy herds.

\section{MATERIALS AND METHODS Data collection}

Milk volume, somatic cell count (SCC) and TBC data were made available by a major Irish milk processor during 2004 to 2007 . Milk on these farms was collected every one to four days, with TBC measured every second week and SCC measured weekly. Herd selection and data collection for this study have been described previously (Kelly et al. 2008). Briefly, annual herd milk supply in 2004 was divided into increments of 10,000 litres with herds supplying yields at either end of the supply distribution being merged due to small strata sizes. A total of 450 herds, of which 400 (89\%) decided to take part in the study, were randomly chosen, with the percentage selected from each stratum being weighted by the frequency of herds within strata relative to the sample population.

Table 1: Association between milking process infrastructure components/ variables and bulk tank total bacterial score (TBS)

\begin{tabular}{|c|c|c|c|c|c|}
\hline Variable & Level & $\%$ & TBS $\left(\mathrm{TBC}^{1}\right)$ & S. Error & P-value ${ }^{2}$ \\
\hline \multirow{4}{*}{$\begin{array}{l}\text { Number } \\
\text { of milking } \\
\text { cows }\end{array}$} & $67-293$ & 24 & $9.89(20)$ & 0.045 & 0.0642 \\
\hline & $51-66$ & 23 & $9.92(20)$ & 0.044 & \\
\hline & $37-50$ & 28 & 9.85 (19) & 0.041 & \\
\hline & $12-36$ & 25 & $10.00(22)$ & 0.043 & \\
\hline \multirow{2}{*}{$\begin{array}{l}\text { Automatic } \\
\text { cluster } \\
\text { removers }\end{array}$} & Yes & 5 & $9.76(17)$ & 0.093 & 0.0924 \\
\hline & No & 95 & 9.92 (20) & 0.022 & \\
\hline \multirow{2}{*}{$\begin{array}{l}\text { Heated } \\
\text { water in } \\
\text { parlour }\end{array}$} & Yes & 40 & 9.82 (18) & 0.035 & 0.0002 \\
\hline & No & 60 & 9.99 (22) & 0.028 & \\
\hline \multirow{2}{*}{$\begin{array}{l}\text { Frequency } \\
\text { of liner } \\
\text { change }\end{array}$} & $\leq$ once a year & 64 & $9.95(21)$ & 0.027 & 0.0178 \\
\hline & $>$ once a year & 36 & 9.84 (19) & 0.036 & \\
\hline \multirow[t]{3}{*}{ Filter used } & Sock filter & 71 & $9.90(20)$ & 0.026 & 0.4361 \\
\hline & Solid filter & 10 & $9.89(20)$ & 0.069 & \\
\hline & No filter & 19 & $9.97(21)$ & 0.049 & \\
\hline
\end{tabular}

${ }^{1}$ Back transformed total bacterial count (TBC) $10^{3} / \mathrm{ml}$.

${ }^{2} \mathrm{P}$-value is significant at less than $\mathbf{0 . 0 5}$
Table 2: Association between teat preparation and disinfection methods and bulk tank total bacterial score (TBS)

\begin{tabular}{|c|c|c|c|c|c|}
\hline Variable & Level & $\%$ & TBS $\left(\mathrm{TBC}^{1}\right)$ & $\begin{array}{l}\text { S. } \\
\text { Error }\end{array}$ & P-value ${ }^{2}$ \\
\hline \multirow{5}{*}{$\begin{array}{l}\text { Teat preparation } \\
\text { spring (Jan-Apr) }\end{array}$} & Wash only & 22 & 9.88 (19) & 0.047 & 0.8461 \\
\hline & $\begin{array}{l}\text { Wash and dry } \\
\text { with paper towel }\end{array}$ & 5 & $9.89(20)$ & 0.095 & \\
\hline & $\begin{array}{l}\text { Wash and dry } \\
\text { with common } \\
\text { cloth }\end{array}$ & 3 & 9.88 (19) & 0.119 & \\
\hline & Dry wipe & 24 & $9.91(20)$ & 0.044 & \\
\hline & None & 46 & $9.94(21)$ & 0.032 & \\
\hline \multirow{5}{*}{$\begin{array}{l}\text { Teat preparation } \\
\text { summer (May- } \\
\text { Sep) }\end{array}$} & Wash only & 16 & 9.85 (19) & 0.054 & 0.7019 \\
\hline & $\begin{array}{l}\text { Wash and dry } \\
\text { with paper towel }\end{array}$ & 2 & $9.82(18)$ & 0.152 & \\
\hline & $\begin{array}{l}\text { Wash \& dry with } \\
\text { common cloth }\end{array}$ & 2 & 9.86 (19) & 0.143 & \\
\hline & Dry wipe & 26 & $9.93(20)$ & 0.043 & \\
\hline & None & 54 & $9.93(21)$ & 0.029 & \\
\hline \multirow{5}{*}{$\begin{array}{l}\text { Teat preparation } \\
\text { winter (Oct-Dec) }\end{array}$} & Wash only & 22 & $9.92(20)$ & 0.046 & 0.5008 \\
\hline & $\begin{array}{l}\text { Wash and dry } \\
\text { with paper towel }\end{array}$ & 7 & 9.84 (19) & 0.084 & \\
\hline & $\begin{array}{l}\text { Wash and dry } \\
\text { with common } \\
\text { cloth }\end{array}$ & 4 & $9.76(17)$ & 0.105 & \\
\hline & Dry wipe & 22 & $9.92(20)$ & 0.047 & \\
\hline & None & 45 & $9.94(21)$ & 0.032 & \\
\hline \multirow{3}{*}{$\begin{array}{l}\text { Disinfecting } \\
\text { after }\end{array}$} & Never & 22 & $10.03(23)$ & 0.045 & 0.0124 \\
\hline & Intermittently & 9 & $9.94(21)$ & 0.071 & \\
\hline & Every milking & 69 & 9.87 (19) & 0.026 & \\
\hline
\end{tabular}

${ }^{1}$ Back transformed total bacterial count (TBC) $10^{3} / \mathrm{ml}$.

${ }^{2} \mathrm{P}$-value is significant at less than $\mathbf{0 . 0 5}$

Two questionnaires were administrated during a faceto-face interview with each farmer, between April and July 2006 ('summer') and between December 2006 and March 2007 ('winter'). The summer questionnaire related mainly to the milking process and infrastructure, and the winter questionnaire to cow accommodation. The survey questions required objective measurements and factual responses from the farmer, as well as subjective measures. A scoring system for cow cleanliness based on Ruegg's score sheet (2004), where a random sample of ten cows on each farm was assigned a composite score of one (clean) to four (very dirty) based on the component score of the udder, tail and legs. An overall (herd) cow cleanliness score was calculated by adding the individual cow scores. Farms were divided into five regions based on geographical location. Any potential temporal-spatial bias was minimised by altering the order of farm visits within each region.

As described previously by Kelly et al. (2008), a milk sample was collected following agitation from the bulk tank of $\mathbf{3 0 0}$ farms during the summer visit. There were only 300 samples taken as the bulk tank milk had been collected by the processor before the arrival of the survey personal to the remaining farms. Each sample was collected in individual sterile sample bottles and stored frozen prior to processing. After thawing, $10 \mu \mathrm{l}$ from each 
Table 3: Association between summer management practices and bulk tank total bacterial score (TBS)

\begin{tabular}{|c|c|c|c|c|c|}
\hline Variable & Level & $\%$ & TBS $\left(\mathrm{TBC}^{1}\right)$ & $\begin{array}{l}\text { S. } \\
\text { Error }\end{array}$ & P-value ${ }^{2}$ \\
\hline \multirow{2}{*}{$\begin{array}{l}\text { Milk recording } \\
\text { practiced }\end{array}$} & Yes & 49 & $9.80(18)$ & 0.030 & $<0.001$ \\
\hline & No & 51 & $10.03(23)$ & 0.030 & \\
\hline \multirow{2}{*}{$\begin{array}{l}\text { Gloves worn } \\
\text { during milking }\end{array}$} & Yes & 37 & $9.92(20)$ & 0.035 & 0.8614 \\
\hline & No & 63 & $9.91(20)$ & 0.027 & \\
\hline \multirow[t]{3}{*}{$\begin{array}{l}\text { Management } \\
\text { of cow tails }\end{array}$} & $\begin{array}{l}\text { Clip tails > } \\
\text { once a year }\end{array}$ & 48 & 9.84 (19) & 0.031 & 0.0007 \\
\hline & $\begin{array}{l}\text { Clip tails } \\
\text { sonce a year }\end{array}$ & 39 & $10.02(22)$ & 0.034 & \\
\hline & $\begin{array}{l}\text { Tails ringed/ } \\
\text { cut }\end{array}$ & 14 & 9.88 (19) & 0.058 & \\
\hline \multirow{2}{*}{$\begin{array}{l}\text { Walk ways } \\
\text { washed before } \\
\text { milking }\end{array}$} & Yes & 45 & 9.83 (19) & 0.032 & 0.0002 \\
\hline & No & 55 & $9.99(22)$ & 0.029 & \\
\hline
\end{tabular}

${ }^{1}$ Back transformed total bacterial count (TBC) $10^{3} / \mathrm{ml}$.

${ }^{2} \mathrm{P}$-value is significant at less than 0.05

sample was inoculated onto blood agar plates (base no.

2; MERCK product, Manufactured in Merck KGaA 64271

Darmstadt. Germany) and incubated at $37^{\circ} \mathrm{C}$ overnight (1618 hours). Bacteria were visually identified from the plates by an experienced laboratory technician after incubation.

\section{Statistical analysis}

As TBC data were positively skewed, the variable total bacterial score (TBS) was calculated as the average of the natural logarithm of the bulk tank TBC for all milk collections in the 365 days prior to the first visit to a specific farm. Data regarding a wide range of independent variables were available from the two questionnaires, relating to the milking process infrastructure (14 variables), teat preparation and disinfection methods (seven variables), summer management practices (18 variables), winter management practices (nine variables), parlour and roadway hygiene (ten variables) and the hygiene of winter housing (17 variables) on each study farm. Data information from each questionnaire that was completed on-farm, was entered into Microsoft Excel, where the data was managed for ease of analysis. The milk processing data was also managed using Microsoft Excel. The two sets of data were combined using SAS Institute Inc. US. The association between TBS and each of these independent variables was assessed separately using linear fixed effects models developed with PROC GLM (SAS 2006); TBS was the dependent variable and geographic location was a confounding variable. Independent variables associated with TBS at $\mathrm{P}<0.30$ were retained for further analysis. Multiple regression models were then developed with PROC GLM using stepwise regression. Separate multiple regression models were generated using independent variables from the summer questionnaire, from the winter questionnaire and from both questionnaires. Statistical significance for all final multiple regression models was defined as $\mathrm{P}<0.05$.

The relationship between the bacterial plate counts and TBS was determined using PROC GLM (SAS 2006). The
Table 4: Association between winter management practices and bulk tank total bacterial score (TBS)

\begin{tabular}{|c|c|c|c|c|c|}
\hline Variable & Level & $\%$ & TBS $\left(\mathrm{TBC}^{1}\right)$ & S. Error & P-value ${ }^{2}$ \\
\hline \multirow[t]{5}{*}{ Cow housing } & Cubicles & 84 & $9.93(21)$ & 0.024 & 0.0611 \\
\hline & Loose & 5 & 9.95 (21) & 0.095 & \\
\hline & Paddock & 2 & $10.30(30)$ & 0.149 & \\
\hline & $\begin{array}{l}\text { Cubicles and } \\
\text { loose }\end{array}$ & 3 & 9.86 (19) & 0.128 & \\
\hline & Stalls & 6 & $10.08(24)$ & 0.086 & \\
\hline \multirow[t]{7}{*}{$\begin{array}{l}\text { Cubicle } \\
\text { bedding }\end{array}$} & $\begin{array}{l}\text { Sawdust and } \\
\text { other }\end{array}$ & 11 & $9.92(20)$ & 0.066 & 0.0003 \\
\hline & Lime & 17 & $10.01(22)$ & 0.051 & \\
\hline & Shredded paper & 4 & $9.82(18)$ & 0.112 & \\
\hline & Straw & 4 & $10.13(25)$ & 0.104 & \\
\hline & None & 11 & $10.15(26)$ & 0.066 & \\
\hline & Mats & 19 & $9.95(21)$ & 0.048 & \\
\hline & Mats and lime & 34 & $9.82(18)$ & 0.037 & \\
\hline \multirow{5}{*}{$\begin{array}{l}\text { Cubicles } \\
\text { cleaned }\end{array}$} & Twice a day & 37 & $9.82(18)$ & 0.036 & 0.0038 \\
\hline & Once a day & 46 & $10.00(22)$ & 0.032 & \\
\hline & Never & 5 & $9.93(21)$ & 0.094 & \\
\hline & $\begin{array}{l}\text { Every second } \\
\text { day }\end{array}$ & 7 & $9.98(22)$ & 0.085 & \\
\hline & Weekly & 5 & $10.06(23)$ & 0.099 & \\
\hline \multirow[t]{5}{*}{$\begin{array}{l}\text { Passage } \\
\text { cleaning }\end{array}$} & $\begin{array}{l}\text { Mechanical } \\
\text { scrapers }\end{array}$ & 55 & $9.92(20)$ & 0.029 & 0.0625 \\
\hline & Tractor & 23 & $10.04(24)$ & 0.046 & \\
\hline & Hand scraper & 6 & $10.01(22)$ & 0.094 & \\
\hline & Slats & 11 & 9.85 (19) & 0.068 & \\
\hline & Mixture & 5 & $9.82(18)$ & 0.092 & \\
\hline \multirow{7}{*}{$\begin{array}{l}\text { Frequency } \\
\text { of passage } \\
\text { cleaning }\end{array}$} & Twice a day & 16 & $9.95(21)$ & 0.059 & 0.2083 \\
\hline & Once a day & 24 & $10.04(23)$ & 0.049 & \\
\hline & Never & 1 & $10.25(28)$ & 0.245 & \\
\hline & $\begin{array}{l}\text { Every one to } \\
\text { two hrs }\end{array}$ & 11 & $9.88(20)$ & 0.071 & \\
\hline & $\begin{array}{l}\text { Every three to } \\
\text { four hrs }\end{array}$ & 32 & $9.89(20)$ & 0.042 & \\
\hline & $\begin{array}{l}\text { Every five to } \\
\text { seven hrs }\end{array}$ & 12 & $9.90(20)$ & 0.067 & \\
\hline & Twice a week & 4 & $10.01(22)$ & 0.123 & \\
\hline \multirow[t]{5}{*}{ Calving area } & Calving box & 85 & $9.94(21)$ & 0.023 & 0.0103 \\
\hline & Cubicles house & 4 & $9.68(16)$ & 0.112 & \\
\hline & Paddock & 4 & $10.16(26)$ & 0.112 & \\
\hline & Stalls & 3 & $10.17(26)$ & 0.121 & \\
\hline & Other & 5 & 9.88 (19) & 0.101 & \\
\hline \multirow{6}{*}{$\begin{array}{l}\text { Frequency } \\
\text { of calving } \\
\text { area } \\
\text { cleaned }\end{array}$} & Daily & 23 & $9.97(21)$ & 0.048 & 0.8697 \\
\hline & Twice a week & 17 & $9.95(21)$ & 0.054 & \\
\hline & Weekly & 11 & $9.94(21)$ & 0.065 & \\
\hline & $\begin{array}{l}\text { Three times per } \\
\text { calving season }\end{array}$ & 15 & $9.90(20)$ & 0.058 & \\
\hline & $\begin{array}{l}\text { Twice during } \\
\text { calving season }\end{array}$ & 24 & $9.92(20)$ & 0.046 & \\
\hline & $\begin{array}{l}\text { End of calving } \\
\text { season }\end{array}$ & 10 & $10.00(22)$ & 0.071 & \\
\hline
\end{tabular}

${ }^{1}$ Back transformed total bacterial count (TBC) $10^{3} / \mathrm{ml}$.

${ }^{2} \mathrm{P}$-value is significant at less than $\mathbf{0 . 0 5}$

correlation between the somatic cell score (SCS is the average of the natural logarithm of the bulk tank somatic 


\section{Table 5: Association between parlour and roadway hygiene and bulk tank total} bacterial score (TBS)

\begin{tabular}{|c|c|c|c|c|c|}
\hline Variable & Level & $\%$ & TBS $\left(\mathrm{TBC}^{1}\right)$ & $\begin{array}{l}\text { S. } \\
\text { Error }\end{array}$ & P-value \\
\hline \multirow{3}{*}{$\begin{array}{l}\text { Cleanliness of } \\
\text { the parlour }\end{array}$} & Clean & 43 & 9.88 (19) & 0.033 & \multirow[t]{3}{*}{0.0047} \\
\hline & Slightly dirty & 48 & $9.90(20)$ & 0.031 & \\
\hline & Dirty & 9 & $10.14(25)$ & 0.074 & \\
\hline \multirow{3}{*}{$\begin{array}{l}\text { Cleanliness of } \\
\text { milking unit } \\
\text { claw piece }\end{array}$} & Clean & 42 & 9.83 (19) & 0.033 & \multirow[t]{3}{*}{$<0.001$} \\
\hline & Slightly dirty & 45 & $9.93(21)$ & 0.032 & \\
\hline & Dirty & 13 & $10.13(25)$ & 0.059 & \\
\hline \multirow{3}{*}{$\begin{array}{l}\text { Condition of } \\
\text { the milking } \\
\text { unit liners }\end{array}$} & New & 82 & $9.90(20)$ & 0.024 & \multirow[t]{3}{*}{0.1551} \\
\hline & $\begin{array}{l}\text { Slightly } \\
\text { cracked }\end{array}$ & 12 & $10.03(23)$ & 0.065 & \\
\hline & Cracked & 7 & $9.93(21)$ & 0.086 & \\
\hline \multirow{7}{*}{$\begin{array}{l}\text { Collecting } \\
\text { yard cleaning } \\
\text { frequency }\end{array}$} & $\begin{array}{l}\text { After every } \\
\text { milking }\end{array}$ & 17 & $9.90(20)$ & 0.053 & \multirow[t]{7}{*}{0.1686} \\
\hline & Daily & 37 & 9.85 (19) & 0.035 & \\
\hline & Weekly & 15 & $9.95(21)$ & 0.056 & \\
\hline & $\begin{array}{l}\text { Every } \\
\text { second day }\end{array}$ & 13 & $10.02(22)$ & 0.061 & \\
\hline & $\begin{array}{l}\text { Every third } \\
\text { day or twice } \\
\text { a week }\end{array}$ & 6 & $9.91(20)$ & 0.087 & \\
\hline & Slates & 6 & $9.93(21)$ & 0.087 & \\
\hline & $\begin{array}{l}\text { As required } \\
\text { or other }\end{array}$ & 6 & $10.04(23)$ & 0.088 & \\
\hline \multirow{4}{*}{$\begin{array}{l}\text { Cleanliness of } \\
\text { yard }\end{array}$} & Clean & 26 & 9.87 (19) & 0.045 & \multirow[t]{4}{*}{0.1946} \\
\hline & Slightly dirty & 43 & $9.88(20)$ & 0.035 & \\
\hline & Dirty & 27 & $9.98(22)$ & 0.043 & \\
\hline & Very dirty & 4 & $10.01(22)$ & 0.115 & \\
\hline \multirow{4}{*}{$\begin{array}{l}\text { Cleanliness of } \\
\text { road }\end{array}$} & Clean & 25 & 9.86 (19) & 0.044 & \multirow[t]{4}{*}{0.0389} \\
\hline & Slightly dirty & 51 & $9.89(20)$ & 0.030 & \\
\hline & Dirty & 17 & $9.97(21)$ & 0.053 & \\
\hline & Very dirty & 7 & $10.12(25)$ & 0.087 & \\
\hline \multirow{3}{*}{$\begin{array}{l}\text { Condition of } \\
\text { road way }\end{array}$} & Very good & 17 & 9.84 (19) & 0.052 & \multirow[t]{3}{*}{0.0399} \\
\hline & Good & 59 & $9.90(20)$ & 0.028 & \\
\hline & Poor & 24 & $10.00(22)$ & 0.044 & \\
\hline
\end{tabular}

\section{${ }^{1}$ Back transformed total bacterial count (TBC) $10^{3} / \mathrm{mL}$. \\ ${ }^{2}$ P-value is significant at less than $\mathbf{0 . 0 5}$}

cell count for all milk collections in the 365 days prior to the first visit to a specific farm) and TBS was calculated from the farms in the study, the SCS and TBS used was calculated from the average for each farm for the 365 days prior to the first farm visit.

\section{RESULTS}

Across the 400 study herds, the average number of cows and heifers was 55 (range 12 to 293) and 12 (0 to $67)$, respectively. There was a wide range in milk volume supplied to the processor in the 365 days prior to the farm visit varying from 17,087 to $1,324,474$ litres. The average farm TBC for the 365 days prior to the visit to the study farms ranged from 10,441 to 130,458 cells/ $\mathrm{ml}$; the median TBC of all farms was 18,483 cells $/ \mathrm{ml}$. There was a correlation of 0.27 between SCS and TBS. S. aureus was present in $51 \%$ of the 300 bulk tank samples, varying from one CFU/10 $\mu$ l to 'numerous' (i.e., 40 to $100 \mathrm{CFU} / 10 \mu \mathrm{l}) ; 11 \%$ of all milk samples had more than $40 \mathrm{CFU} / 10 \mu \mathrm{l}$. No other mastitis pathogens were isolated. There was no significant association between the level of $S$. aureus and TBS.

Tables 1 to 6 describe the associations between bulk tank TBS and milking process infrastructure, teat preparation, herd management, winter housing, parlour and roadway hygiene and the hygiene of winter housing, respectively, on 400 farms. Not all milking parlour infrastructure variables were associated with bulk tank TBS (Table 1). The presence of heated water in the parlour was also associated $(P<0.001)$ with lower TBS. As the frequency of liner changing increased, the level of TBS decreased. Approximately half of farms surveyed in this study practised some form of teat preparation (Table 2), but there was no association between teat preparation and TBS. However, lower $(\mathrm{P}<0.05)$ TBS was observed on farms that disinfected teats after every milking. Participating in a milk recording programme, of which $49 \%$ of farmers did, was shown to have lower $(\mathrm{P}<0.001)$ bulk tank TBS than not participating.

Cleanliness of the farm, housing and milking parlour was strongly associated $(\mathrm{P}<0.05)$ with lower herd TBS (Tables 4-6). Bulk tank TBS was lower in herds with clean facilities and those herds that used shredded paper or lime and mats under the cows during housing $(P<0.001)$. Tables 7-9 summarise the summer, winter and combined management factors on the 400 farms that were significantly associated with bulk tank TBS, respectively, in the multiple regression models; the models had r-squared measurements of $0.191620,0.197630$ and 0.193459 respectively. These include the condition of the housing, washing of walkways in the parlour, bedding type, tail clipping, practicing milk recording, and whether or not heated water was available in the milking parlour. Residual diagnostics did not indicate any concern for departures from the statistical assumptions of constant variability and normality.

Additionally, when the combined management factor regression model was developed, the cumulative effect of best practices, such as participation in a milk recording scheme, heated water in the parlour, washing of the walkways before milking, the shed in good condition, tails ringed or clipped at a frequency of greater then once a year and clean cubicles, was calculated as 20,167 cells/ $\mathrm{ml}$, i.e., milk TBC was expected to be 20,167 cells $/ \mathrm{ml}$ lower when these best practices were in place compared to the poorest alternative within each variable. However, this difference would only be seen if the practices were in place on a farm and they were causal. 
Table 6: Association between degree of hygiene of cow accommodation and bulk tank total bacterial score (TBS)

\begin{tabular}{|l|l|l|l|l|l|}
\hline Variable & Level & $\%$ & TBS (TBC $)$ & $\begin{array}{l}\text { S. } \\
\text { Error }\end{array}$ & P-value $^{2}$ \\
\hline $\begin{array}{l}\text { Cleanliness of } \\
\text { loafing area }\end{array}$ & $\begin{array}{l}\text { Clean } \\
\text { Slightly dirty }\end{array}$ & 43 & $9.87(19)$ & 0.033 & 0.0023 \\
\hline & Dirty & 14 & $9.97(21)$ & 0.033 & \\
\hline $\begin{array}{l}\text { Condition of } \\
\text { cubicle shed }\end{array}$ & Very good & 9 & $9.95(21)$ & 0.071 & $<0.001$ \\
\hline & Good & 85 & $9.91(20)$ & 0.023 & \\
\hline $\begin{array}{l}\text { Cleanliness of } \\
\text { cubicles }\end{array}$ & Clean & 6 & $10.33(31)$ & 0.088 & \\
\hline Slightly dirty & 35 & $9.87(19)$ & 0.028 & $<0.001$ \\
\hline $\begin{array}{l}\text { Cow } \\
\text { cleanliness } \\
\text { score }(0\end{array}$ & Dirty & 9 & $9.98(22)$ & 0.036 & \\
$\begin{array}{l}\text { clean to } 120 \\
\text { dirty) }\end{array}$ & $<60$ & 19 & $9.86(19)$ & 0.050 & 0.0603 \\
\hline & $>59$ & 16 & $9.95(21)$ & 0.027 & \\
\hline
\end{tabular}

${ }^{1}$ Back transformed total bacterial count (TBC) $10^{3} / \mathrm{ml}$.

${ }^{2}$ P-value is significant at less than 0.05

Table 7: Summer herd management factors associated with bulk tank total bacterial score (TBS) on $\mathbf{4 0 0}$ Irish dairy farms, based on a multiple regression model

\begin{tabular}{|c|c|c|c|c|}
\hline Question & Level & TBS $\left(\mathrm{TBC}^{1}\right)$ & S. Error & P-value ${ }^{2}$ \\
\hline \multirow{2}{*}{$\begin{array}{l}\text { Milk recording } \\
\text { practiced }\end{array}$} & Yes & 9.87 (19) & 0.037 & 0.0066 \\
\hline & No & $10.02(23)$ & 0.037 & \\
\hline \multirow{3}{*}{$\begin{array}{l}\text { Cleanliness of claw } \\
\text { piece }\end{array}$} & Clean & 9.86 (19) & 0.035 & 0.0138 \\
\hline & Slightly dirty & $9.92(20)$ & 0.035 & \\
\hline & Dirty & $10.06(23)$ & 0.063 & \\
\hline \multirow[t]{2}{*}{$\begin{array}{l}\text { Cow tail } \\
\text { management }\end{array}$} & $\begin{array}{l}\text { Clip tails > } \\
\text { once a year }\end{array}$ & 9.86 (19) & 0.034 & 0.0043 \\
\hline & $\begin{array}{l}\text { Clip tails } \leq \\
\text { once a year }\end{array}$ & $10.02(22)$ & 0.039 & \\
\hline \multirow[t]{3}{*}{$\begin{array}{l}\text { Walk ways washed } \\
\text { before milking }\end{array}$} & $\begin{array}{l}\text { Tails ringed/ } \\
\text { cut }\end{array}$ & $9.96(21)$ & 0.06 & \\
\hline & Yes & $9.88(20)$ & 0.039 & 0.0067 \\
\hline & No & $10.01(22)$ & 0.033 & \\
\hline \multirow{2}{*}{$\begin{array}{l}\text { Heated water in } \\
\text { the pit }\end{array}$} & Yes & $9.89(20)$ & 0.038 & 0.0090 \\
\hline & No & $10.00(22)$ & 0.034 & \\
\hline
\end{tabular}

${ }^{1}$ Back transformed total bacterial count (TBC) $10^{3} / \mathrm{ml}$.

${ }^{2} \mathrm{P}$-value is significant at less than $\mathbf{0 . 0 5}$

\section{DISCUSSION}

Milk quality is important for both the economics and perception of milk production in Ireland and therefore, herd management factors associated with milk quality need to be accurately quantified. Hence, the objective of this study was to quantify the association between bulk tank TBS and herd management factors. It should be noted due to the design of the study, that the associations reported within do not imply cause and effect, and should not be interpreted as such. Purpose of the study was to identify factors that have greatest association with TBC, the detail of which could then be established in further experimental trails. The farms in the current study would be considered to be representative of the national population as they have similar SCC and TBC to those farms used by Berry et al. (2006) who used $40 \%$ of the national population of dairy farmers.

In the multi-regression models of summer and winter management factors, nine factors were identified as being significantly associated with TBS. Most of these variables have also been observed as significant in previous research (Olson and Mocquat 1980; Zehner et al. 1986; Magnusson et al. 2006).

The lower TBS observed in herds that practised milk recording was not unexpected, given the correlation $(0.27)$ between TBS with SCS, and the fact that involvement in a milk recording scheme was associated with lower SCS (Kelly et al. 2008). Some studies have indicated deterioration in udder health (Dohoo and Leslie 1991) when SCC increased to greater than 200,000 cells $/ \mathrm{ml}$. Milk recording would allow the cows with high SCC to be identified and subsequently removed from the herd, resulting in a concomitant reduction in TBS.

Murphy et al. (2005) documented that the low microbial load in the milk of the cows getting no teat preparation in their trial, was a reflection of the importance of housing and milking parlour hygiene in decreasing TBC. Magnusson et al. (2006) reported that not all bacterial spores are removed even with the best cleaning method, therefore it is important to maintain good hygiene at all stages of milk production. Milk handling equipment can become contaminated due to poor hygiene and cleaning, the bacteria in turn can pass into the milk line, thus increasing TBC (Olson and Mocquat 1980). These observations are in agreement with the current study, where heated water in the parlour along with greater hygiene of the parlour, claw piece and cubicle house, as well as improved maintenance and condition of the cubicle house, were significantly associated with lower TBS. Increased frequency of tail clipping had a significant association with lower TBS. Schreiner and Ruegg (2002) did not identify differences in milk quality that could be attributed to tail docking; however, their study compared cut tails to an unclipped tail, whereas the current study looked at the frequency of clipping and showed the difference between the frequencies.

Schreiner and Ruegg (2003) also reported that the primary sources of exposure of environmental mastitis pathogens to the cow were the presence of moisture, mud and manure in the environment of the cow. A higher frequency of cubicle cleaning and also specific bedding material types were associated with lower bulk tank TBS in the current study. The association between bacterial counts and bedding materials is well researched; Hogan et al. (1997) and Galton et al. (1982) showed that both used and unused organic bedding had bacteria present, while Zehner et al. (1986) reported that clean, damp bedding can support bacterial growth. Rendos et al. (1975) found that the populations of bacteria increased in the bedding material after use, while Zdanowicz et al. (2004) showed that bacterial counts in sawdust were correlated with bacterial counts on the teat ends. Hogan et al. (1989) also documented that bacterial populations 
Table 8: Winter herd management factors associated with bulk tank total bacterial score (TBS) on 400 Irish dairy farms, based on a multiple regression model

\begin{tabular}{|l|l|l|l|l|}
\hline Question & Level & TBS $\left(\right.$ TBC $\left.^{1}\right)$ & S. Error & P-value \\
\hline $\begin{array}{l}\text { Condition of } \\
\text { cubicle shed }\end{array}$ & Very good & $10.13(25)$ & 0.087 & 0.0025 \\
& Good & $10.00(22)$ & 0.053 & \\
& Poor & $10.29(29)$ & 0.095 & \\
\hline $\begin{array}{l}\text { Cleanliness } \\
\text { of cubicles }\end{array}$ & Clean & $10.05(23)$ & 0.062 & 0.0349 \\
& Slightly dirty & $10.15(26)$ & 0.064 & \\
& Dirty & $10.22(28)$ & 0.085 & \\
\hline Calving area & Calving box & $10.11(25)$ & 0.044 & 0.0006 \\
& Cubicles house & $9.83(19)$ & 0.111 & \\
& Paddock & $10.22(28)$ & 0.117 & \\
& Stalls & $10.58(39)$ & 0.153 & \\
& Other & $9.96(21)$ & 0.100 & \\
\hline Cubicle & Sawdust and other & $10.09(24)$ & 0.082 & 0.0049 \\
\hline bedding of & Lime & $10.17(26)$ & 0.072 & \\
& Shredded paper & $9.94(21)$ & 0.120 & \\
& Straw & $10.31(30)$ & 0.109 & \\
& None & $10.30(30)$ & 0.082 & \\
& Mats & $10.13(25)$ & 0.072 & \\
& Mats and lime & $10.04(23)$ & 0.069 & \\
\hline
\end{tabular}

${ }^{1}$ Back transformed total bacterial count (TBC) $10^{3} / \mathrm{ml}$.

${ }^{2}$ P-value is significant at less than $\mathbf{0 . 0 5}$

differed both over the season of the year and types of bedding material.

The presence of only one bacteria type in the milk samples of the current study could be due to the milk samples having been taken during the period when cows were grazing outdoors, thus reducing the likelihood of environmental bacteria presence. Also, the bulk tank samples were frozen which may have limited the presence of bacteria in the samples. Schukken et al. (1989) reported a reduction in the level of $E$. coli or Actinomyces pyogenes after freezing the milk samples; Luedecke et al. (1972) also documented that the presence of $S$. agalactiae decreased in milk samples after freezing at minus $20^{\circ} \mathrm{C}$ for 70 days.

\section{CONCLUSIONS}

This study described work practices and facilities on a representative sample of Irish dairy cattle farms. It also indicated the association of milk TBS with different management practices and farm infrastructure. Some of the management practices associated with low TBC included use of heated water, participation in a milk recording scheme, tail clipping of cows at a frequency greater than once per year. Additionally an increased level of hygiene of the parlour, cubicle houses and roadways was also associated with low TBC.

\section{ACKNOWLEDGEMENTS}

The participating milk processor and farmers are gratefully acknowledged for their contribution to this study.

\section{REFERENCES}

Berry DP, O'Brien B, O'Callaghan EJ et al. (2006) Temporal
Table 9: Overall herd management factors associated with bulk tank Total bacterial score (TBS) on $\mathbf{4 0 0}$ Irish dairy farms, based on a multiple regression model

\begin{tabular}{|c|c|c|c|c|}
\hline Question & Level & TBS $\left(\mathrm{TBC}^{1}\right)$ & $\begin{array}{l}\text { S. } \\
\text { Error }\end{array}$ & P-value ${ }^{2}$ \\
\hline \multirow{2}{*}{$\begin{array}{l}\text { Milk recording } \\
\text { practiced }\end{array}$} & Yes & $9.95(21)$ & 0.047 & \multirow[t]{2}{*}{0.0024} \\
\hline & No & $10.09(24)$ & 0.047 & \\
\hline \multirow{2}{*}{$\begin{array}{l}\text { Heated water } \\
\text { in the pit }\end{array}$} & Yes & $9.96(21)$ & 0.049 & \multirow[t]{2}{*}{0.0058} \\
\hline & No & $10.08(24)$ & 0.045 & \\
\hline \multirow{2}{*}{$\begin{array}{l}\text { Walk ways } \\
\text { washed before } \\
\text { milking }\end{array}$} & Yes & $9.96(21)$ & 0.048 & \multirow[t]{2}{*}{0.0069} \\
\hline & No & $10.08(24)$ & 0.045 & \\
\hline \multirow{3}{*}{$\begin{array}{l}\text { Condition of } \\
\text { cubicle shed }\end{array}$} & Very good & $10.01(22)$ & 0.074 & \multirow[t]{3}{*}{0.0039} \\
\hline & Good & $9.89(20)$ & 0.033 & \\
\hline & Poor & $10.17(26)$ & 0.090 & \\
\hline \multirow[t]{3}{*}{$\begin{array}{l}\text { Cow tail } \\
\text { management }\end{array}$} & $\begin{array}{l}\text { Clip tails > once } \\
\text { a year }\end{array}$ & $9.95(21)$ & 0.047 & \multirow[t]{3}{*}{0.0335} \\
\hline & $\begin{array}{l}\text { Clip tails } \leq \text { once } \\
\text { a year }\end{array}$ & 10.07 (24) & 0.045 & \\
\hline & Tails ringed/cut & $10.04(23)$ & 0.066 & \\
\hline \multirow{3}{*}{$\begin{array}{l}\text { Cleanliness of } \\
\text { cubicles }\end{array}$} & Clean & $9.96(21)$ & 0.045 & \multirow[t]{3}{*}{0.0432} \\
\hline & Slightly dirty & $10.07(24)$ & 0.051 & \\
\hline & Dirty & $10.03(23)$ & 0.075 & \\
\hline
\end{tabular}

\section{${ }^{1}$ Back transformed total bacterial count (TBC) $10^{3} / \mathrm{ml}$. \\ ${ }^{2} \mathrm{P}$-value is significant at less than $\mathbf{0 . 0 5}$}

trends in bulk tank somatic cell count and total bacterial count in Irish dairy herds during the past decade. Journal of Dairy Science 89, 4083-4093.

Blowey R, Edmondson P (1995) Mastitis control in dairy herds. Ipswich, UK: Farming Press Books, Miller Freeman Professional Ltd.

Bramley AJ, McKinnon C.H. (1990) The microbiology of raw milk. In: Dairy Microbiology. 1, 63-208 Robinson, RK (ed.) London, Elsevier Science Publishers.

Dohoo IR, Leslie KE (1991) Evaluation of changes in somatic cell counts as indicators of new intramammary infections. Preventive Veterinary Medicine 10, 225-238.

European Economic Community (1992) Council Directive 92/46/EEC. Commission Document 39L0046. June 1992. EEC, Brussels, Belgium.

Galton DM, Adkinson RW, Thomas CV et al. (1982). Effects of premilking udder preparation on environmental bacterial contamination of milk. Journal of Dairy Science 65, 1540-1543.

Gilmour A, Rowe MT (1990) Micro-organisms associated with milk. Robinson RK (ed.) In: Dairy Microbiology. 1, 37-114. London, Elsevier Science Publishers.

Goldberg JJ, Wildman EE, Pankey JW et al. (1992) The influence of intensively managed rotational grazing, traditional continuous grazing, and confinement housing on bulk tank milk quality and udder health. Journal of Dairy Science 75, 96-104.

Hayes MC, Ralyea RD, Murphy SC et al. (2001)

Identification and characterisation of elevated microbial counts in bulk tank raw milk. Journal of Dairy Science 84, 292-298.

Hogan JS, Smith KL, Hoblet KH et al. (1989) Bacterial 
counts in bedding materials used on nine commercial dairies. Journal of Dairy Science 72, 250-258.

Hogan JS, Smith KL, Todhunter DA et al. (1990) Bacterial counts associated with recycled newspaper bedding. Journal of Dairy Science 73, 1756-1761.

Hogan JS, Smith KL (1997) Bacteria counts in sawdust bedding. Journal of Dairy Science 80, 1600-1605.

Jayarao BM, Pillai SR, Sawant AA et al. (2004) Guidelines for monitoring bulk tank milk somatic cell and bacterial counts. Journal of Dairy Science 87, 3561-3573.

Kelly PT, O'Sullivan K, Berry DP et al. (2008) Farm management factors associated with bulk tank somatic cell count in Irish dairy herds during 2006/07. Irish Veterinary Journal. 62:3

Luedecke LO, Forster TL, Williams K et al. (1972) Effect of freezing and storage at $-20^{\circ} \mathrm{C}$ on survival of mastitis pathogens. Journal of Dairy Science 55, 417-418.

Magnusson M, Christiansson A, Svensson B et al. (2006) Effect of different premilking manual teat-cleaning methods on bacterial spores in milk. Journal of Dairy Science 89, 3866-3875.

Murphy PM, Freyne T, Gleeson D et al. (2005) Impact of pre-milking teat preparation practices on milk quality. Physiological and Technical Aspects of Machine Milking. Proceedings of the International Conference held in Nitra, Slovak Republic, 26-28 April. Pp 279280.

Natzke RP (1981) Elements of mastitis control. Journal of Dairy Science 64, 1431-1442.

Olson JC Jr, Mocquat G (1980) Milk and Milk Products. In: Microbial Ecology of Foods. 2, $470 \mathrm{JH}$ Silliker, RP Elliott, AC Baird-Parker et al. (eds). New York, Academic Press.

Rendos JJ, Eberhart RJ and Kesler EM (1975) Microbial populations of teat ends of dairy cows, and bedding materials. Journal of Dairy Science 58, 1492-1500.

Ruegg PL (2004) Managing for milk quality. University of Wisconsin, Madison. [Online] Available from: www. uwex.edu/milkquality/PDF/managing\%20for\%20 milk\%20quality_english.pdf

SAS® User's Guide (2006) Version 8.2.0 Edition. SAS Inst., Inc., CA [Accessed 1 February, 2008].

Schreiner DA, Ruegg PL (2002) Effects of tail docking on milk quality and cow cleanliness. Journal of Dairy Science 85, 2503-2511.

Schreiner DA, Ruegg PL (2003) Relationship between udder and leg hygiene scores and subclinical mastitis. Journal of Dairy Science 86, 3460-3465.

Schukken YH, Smit JAH, Grommers FJ et al. (1989) Effect of freezing on bacteriologic culturing of mastitis milk samples. Journal of Dairy Science 72, 1900-1906.

Tolle A (1980) The microflora of the udder. In: Factors Influencing the Bacteriological Quality of Raw Milk. Document 120, p4 International Dairy Federation Bulletin.

Zdanowicz M, Shelford JA, Tucker CB et al. (2004) Bacterial populations on teat ends of dairy cows housed in free stalls and bedded with either sand or sawdust. Journal of Dairy Science 87, 1694-1701.

Zehner MM, Farnsworth RJ, Appleman R et al. (1986)

Growth of environmental mastitis pathogens in various bedding materials. Journal of Dairy Science 69, 19321941. 